\title{
PREDICTION MODEL FOR THE PERSISTENCE OF SHARIA MUTUAL FUND PERFORMANCE IN INDONESIAN CAPITAL MARKET
}

\author{
Zaenal Arifin* \\ Universitas Islam Indonesia \\ Sri Mulyati \\ Universitas Islam Indonesia
}

\begin{abstract}
Over the period of 2010 to 2012, the performance of Islamic mutual funds in Indonesia saw a high degree of persistence. However, the persistence rate decreased in the period of 2014 to 2016 . Given such fluctuated rate, this research tries to identify the factors that influence the persistence of the mutual fund performance and, based on these factors, creates the predictive modelling of persistence rate. The samples of the study included all sharia mutual funds offered from 2010 to 2016 in Indonesian capital market. To construct the model, we used the Logit equation, while to evaluate the accuracy of the prediction model, we used the ExpectationPrediction Evaluation with a prediction evaluation for success of 0.5 . The results of this study indicate that, of the whole mutual fund, the best model is a model involving the following variables: (1) the time interval since the mutual fund was launched, (2) the rank of the mutual funds, whether it was at the top 5 within 1-2 years after the launch, and (3) the number of newcomer funds during persistence testing. The level of accuracy of this model, when it was used to predict the whole sharia mutual fund persistence, was $64 \%$. When the model was used to predict the persistence of equity performance of mutual fund, its level of accuracy rose to $77.78 \%$. Whereas in the use to predict the persistence of fixed income mutual funds the accuracy rate amounted to $70 \%$. The persistence of predictive model for mixed funds was based on different factors of compositions: (1) the number of funds under management, (2) the fact whether the mutual funds are in the top 5 within 1-2 years after the launch, and (3) the number of newly coming funds during persistence testing. This model had an accuracy level of $75 \%$. It is expected that this study be used as a guide for investors wishing to invest in sharia mutual funds.
\end{abstract}

Keywords: Sharia Mutual Fund, Performance, Persistence, Predictive Model of Persistence

Received: 29 January 2019

Accepted: 12 June 2020

\section{INTRODUCTION}

Mutual funds are professionally managed financial investment products. Mutual fund companies normally pool funds from the investing public and invest the collected funds in some financial investment products such as stocks, bonds, and money market products. This type of investment

- Corresponding author: Zaenal Arifin, Universitas Islam Indonesia, Jl. Kaliurang Km. 14, 5 Sleman Yogyakarta. Phone: +6281328011270. Email: zaenalarifin.fe@uii.ac.id 
product is a suitable option for investors lacking of knowledge about the capital market or investors lacking of time to observe the development of the capital market.

Mutual funds are growing rapidly in various countries, including sharia mutual funds in Indonesia. Figure 1 below illustrates the development of sharia mutual funds in Indonesia. In the United States, the rapid development of mutual funds has long been noted. Gruber (1996) recorded mutual fund growth in the United States averaging 20\% per year and Zheng (1999) noted that the value of funds managed by mutual fund companies is greater than those deposited in bank savings. The growth of this mutual fund might be attributed to its ability to manage a large amount of funds to diversify the investments well, something which is almost impossible for individual investors with limited funds. The large amount of funds enables the mutual funds to perform block sale transaction, which costs relatively low.

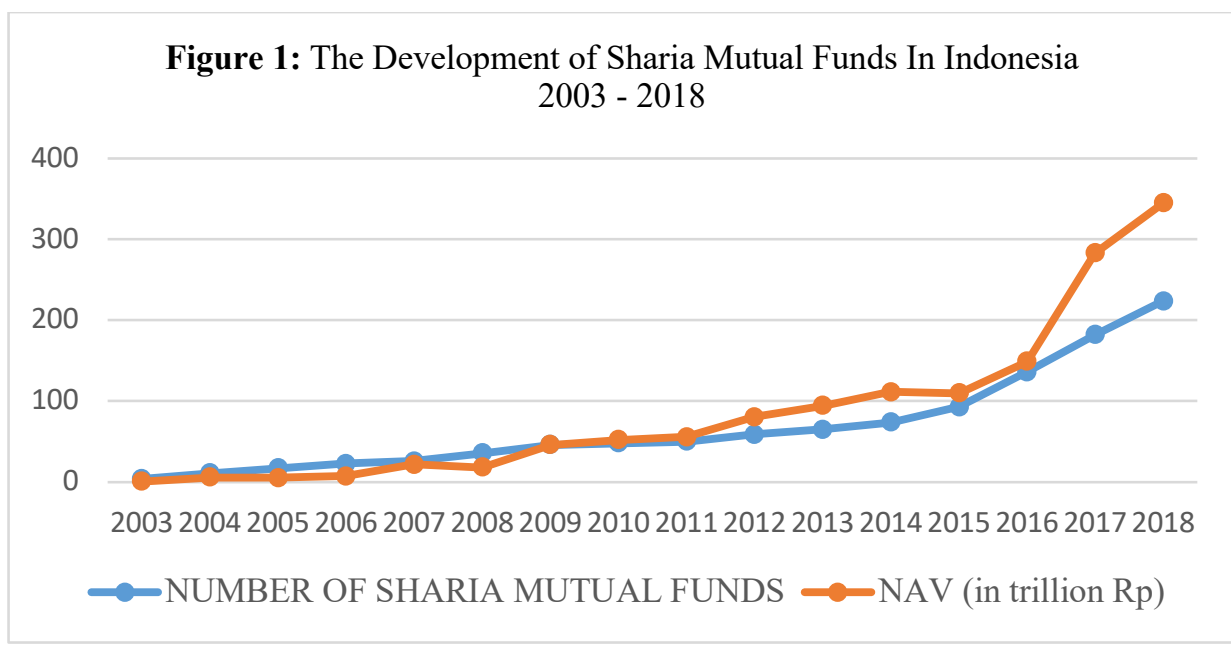

The development of Islamic mutual funds in Indonesia can be due to the performance of Islamic mutual funds over the years. According to Arifin (2018), there has been an increasing percentage of Net Asset Value (NAV) of sharia mutual funds against conventional NAV mutual funds. This indicates that Islamic mutual funds generally provide higher returns than conventional mutual funds. However, a number of studies that compare the performance of Islamic mutual funds and conventional funds do not support this finding. Research conducted by Rahman (2013), Susanto (2012), Romadon (2012) found that the performance of Islamic mutual funds is not always better than that of the conventional ones. Other researchers conducted in other countries, such as in Saudi Arabia by Dabbeeru (2006), in Malaysia by Mansor and Bhatti (2011), and in some countries by Elfakhani, Hassan, and Sidani (2005) and Abderrezak (2008) found no difference between the performance of sharia and conventional mutual funds. In contrast, Hayat and Kraeussl (2012) revealed that the performance of Islamic mutual funds is lower than that of conventional mutual funds. Meanwhile, Rubio, Hassan and Merdad (2012) demonstrated that sharia mutual funds perform better than their international counterparts. 
If the performance of sharia mutual funds is not considered as an advantage, another factor is needed to strengthen its existence as an alternative of investment. Muslim investors might consider halalness as a reference for investment. However, if halalness factor is used as the main reference, it is no longer important to know whether the performance of Islamic mutual funds is better than that of conventional mutual funds. Muslim investors may still want to choose the sharia mutual funds over their counterparts even if the performance or return received is lower than the conventional one. This argument, actually, also applies to investors who choose shares of companies that have social concerns. Although the stock return in the socially responsible investment (SRI) index is not superior to the company's stock in general, according to Jones, Laan, Frost, and Loftus (2008), stocks in the SRI index are still growing. Another reason for investors to choose sharia mutual funds is to diversify investments. Some findings highlighted that the sharia mutual funds excel at bearish market conditions, such as the one found by Mansor and Bhatti (2011). If the reason for choosing a sharia mutual fund is based on an attempt to look for halalness and/or to diversify investments, we need to know how to choose the best from the existing sharia mutual fund.

Gruber (1996) argues that the rapid development of mutual funds in America is due to the persistence of mutual fund performance, which eases the investors in choosing mutual funds. If the performance is persistent, investors can simply choose mutual funds that perform well in the previous period and will reap a good return in the future. Gruber (1996) found a persistence of mutual fund performance in the period of 1985-1994 in the United States. Meanwhile, Grinblat and Titman (1992) also revealed persistent performance in the period of 1974-1984. Similarly, in Indonesia, a number of researchers have conducted a persistence test of mutual fund performance. Using data from 2006 to 2011, Dwianggoro, Anantadjaya, and Sibarani (2012) found no mutual funds that performed persistently for 5 consecutive years. However, they discovered persistent performance in the shorter term when using the index size Jensen and Sharpe, but never revealed persistent result when using the Treynor index. Meanwhile, Elvani and Linawati (2013) obtained a persistence of mutual fund performance for the period of 2008-2012. Thus, the presence or absence of persistence of mutual fund performance in Indonesia is not conclusive yet.

Arifin and Mulyati, (2017) and Arifin (2018) found that in the period of 2010-2012, many sharia mutual funds were performing persistently. Nonetheless, in the period of 2014-2016, only a few sharia mutual funds that showed a persistent performance. On this basis, the remaining question is: what are the factors to cause a mutual fund to perform persistently? Knowing the causes of the persistence of mutual funds' performance will ease the selection of mutual funds, even though the overall persistence level of mutual funds is not highly rated. Unfortunately, no previous studies have ever identified the causes of this persistence.

Carhart (1997) articulated that the determinants of the persistence of equity funds are stock returns and transaction costs. However, the recurring problem is that both information is difficult to obtain by investors. Factors that are used to predict the causes of persistence should be provided as information that most investors can access easily. A number of information about mutual funds that can be accessed by most investors include: the amount of funds under management, the launch date, the status of an investment manager, and the emergence of new players in mutual fund products. Therefore, this research investigates whether these factors influence the persistence of mutual fund performance in Indonesia. If Carhart (1997) only studied equity funds, this research not only investigates equity fund but also examines fixed and mixed-income mutual funds. It is 
expected that this research contributes to complementing the persistence of mutual fund performance studies pioneered by Gruber (1996) and Carhart (1997).

In the following section, in part 2, we will explain the literature review related to the persistence of sharia mutual funds. Meanwhile, section 3 explains the research methodology related to the sample, the measurement of variables, and the predictive model we use. This section is followed by results and discussion in section 4 . Finally, section 5 deals with conclusions of this study.

\section{LITERATURE REVIEW}

Sharia mutual funds are a type of mutual funds that allocate collected funds for investment in securities in accordance with Islamic law. The types of Islamic mutual funds offered equally to those offered by conventional mutual funds, include stock mutual funds, fixed income, mixed income, money markets, protected, and indexes. However, not all securities are included in the portfolio of sharia mutual funds. Sharia equity of mutual funds will only include Sharia shares listed in the List of Sharia Securities at the Indonesia Stock Exchange as an option. Sharia fixed income mutual funds only include sukuk or sharia bonds as an option, while money market mutual funds only include sharia money market products and sharia banking.

In addition to the choice of securities, Islamic mutual fund companies also have a sharia board supervisor. To ensure that securities included in the portfolio are in accordance with the sharia, Sharia mutual fund should be screened and approved by the Sharia Supervisory Board. Sharia regulatory and supervisory rules are binding for mutual fund companies, and investment managers will be assessed by the Sharia supervisory board periodically.

According to Norman (2004), the role of Sharia supervisory board may differ from one mutual fund to another. In addition to the role of endorsement, the sharia supervisory board also has other numerous roles, among of which; studying prospectus, constitutional documents, and each major agreement; advising managers regarding compliance with sharia; as well as preparing annual sharia audits and issuing reports to investors.

The performance of mutual funds is generally measured by Net Asset Value (NAV). As with stocks, to compare the performance of mutual funds with each other, we should express the comparison in the form of returns within a certain period. The investment performance, in general, should pay attention not only to return but also to risks. Measurements that consider returns and risks include Sharpe Measure, Treynor Measure, and Jensen Measure. A performance assessment currently under development is a performance that uses a number of risk factors to eliminate the influence of these factors on the performance of mutual funds. Thus, performance change is entirely seen only from the ability of investment managers in managing funds. Khamlichi, Arouri, and Teulon (2014), for example, include four factors: market premium, size factor, value factor, and momentum factor as a mutual fund performance controller.

Research on the performance of Islamic mutual funds generally compares the performance of Islamic mutual funds with a benchmark. The first benchmark used is market performance. Market performance refers to Islamic stock indexes such as the Jakarta Islamic Index (JII) and the Dow 
Jones Islamic Market Index (DJIM). Rahman (2013), for example, compared the performance of Islamic mutual funds with market performance during the financial crisis of 2008 and found that the performance of Islamic mutual funds at that time was lower than the market performance. At a global level, Rubio, Hassan, and Merdad (2012) highlighted that Islamic mutual funds perform better than their international counterparts.

Another issue that is widely researched is the persistence of mutual fund performance. Gruber (1996) argues that the existence of this persistent performance led to the rapid development of mutual funds in America. He did find a persistence of mutual fund performance in the period 1985 - 1994 in the United States. Meanwhile, Grinblat and Titman (1992) also found persistent performance in the period of 1974-1984. In Indonesia, a number of researches have conducted mutual fund performance persistence test. For example, using data from 2006 to 2011, Dwianggoro et al., (2012) found no mutual funds that performed persistently for 5 consecutive years, but indicated persistence in the shorter term. Meanwhile, Elvani and Linawati (2013) revealed the persistence of mutual fund performance for the period of 2008-2012. Thus, the presence or absence of persistence of mutual fund performance in Indonesia is not conclusive yet.

Currently, there is a limited number of persistent test of Sharia mutual fund. One study to address this issue was done by Khamlichi et al., (2014) using sharia mutual fund data from the Dow Jones Islamic Index from 1999 to 2011. This study found no persistence of Sharia mutual fund performance. Nevertheless, their persistence test is relatively limited because it only compares the recession and expansion periods according to the business cycle of the company.

What are the causes of a persistent mutual fund performance? Carhart (1997) revealed that the persistence of equity fund performance depends on stock returns and investment costs and not because of the fund manager's ability. Carhart (1997) used a 4-factor model, which he developed himself in 1995, to measure mutual fund performance. Unfortunately, Carhart (1997) did not analyze the persistence of fixed-income funds and mixed mutual funds. However, we have not found any related articles that discuss the factors that determine the persistence of sharia mutual fund performance.

\section{METHODOLOGY}

The population of this research are sharia mutual funds in Indonesia. The samples of the study are all sharia mutual funds offered from 2010 to 2016. The sharia mutual funds offered in 2010 were selected to avoid the extreme data of mutual fund performance at the time of the 2008 financial crisis that still retained its impact until 2009. This study used 62 sharia mutual funds as a sample, consisting of 25 equity funds, 16 fixed income funds, and 21 mixed funds.

This research used 6 variables. Performance persistence variables (PERS) were measured by looking at whether a mutual fund was in the top 5 based on the return within a given year, or was still in the top 5 the following year. If the mutual funds were still in the top 5, it would be scored 1 (persistent). Otherwise, it would score 0 (not persistent). This research also used 5 variables to predict persistence. The first variable is total funds under management (FUND). This research used the amount of managed fund at the beginning of the year before the persistence test year. The managed fund is listed in IDR trillion. The second variable is the time interval since the fund was 
launched (LAUNCH), which was measured from the year of the launch of the mutual fund up to the year of observation. The third variable is the owners of mutual funds $(\mathrm{OWN})$, whether they are investment managers or custodian banks that are grouped into domestic owners and foreign owners. The foreign investment manager or custodian bank was scored 1, while the domestic investment manager or custodian bank was scored 0 . The fourth variable is whether the mutual fund is new or not (NEW). Mutual funds were considered new if they were in the top 5 for 1-2 years after the launch. The new mutual fund was scored 1 , while those launched 2 years ago was scored 0 . The fifth variable is the number of new mutual funds (ADNEW) in the persistence test year.

To test whether the five variables above influence the persistence of mutual funds performance, we used the following Logit equation model:

$$
\begin{aligned}
& \mathrm{L}_{\mathrm{i}}=\ln \left[\mathrm{P}_{\mathrm{i}} /\left(1-\mathrm{P}_{\mathrm{i}}\right)\right]=\beta_{1}+\beta_{2} \mathrm{FUND}_{\mathrm{i}}+\beta_{2} \mathrm{LAUNCH}_{\mathrm{i}}+\beta_{2} \mathrm{OWN}_{\mathrm{i}}+\beta_{2} \mathrm{NEW}_{\mathrm{i}}+\beta_{2} \mathrm{ADNEW}_{\mathrm{i}} \\
& \text { where, }, \ln \quad=\text { natural } \log \\
& \mathrm{Pi} \quad=\text { probability of persistence }(\mathrm{Y}=1) \\
&(1-\mathrm{Pi})=\text { prob. No persistence }(\mathrm{Y}=0)
\end{aligned}
$$

To get the best model for predicting persistency, we simulated a number of combinations of the variables above. First, we predicted the persistence of sharia mutual funds as a whole and then proceeded by predicting the persistence of each type of mutual fund. To evaluate the accuracy of the prediction model, we used the Expectation-Prediction Evaluation with a prediction evaluation for success of 0.5 .

\section{RESULTS AND DISCUSSION}

\subsection{Results}

To predict the persistence of mutual fund performance, we used Logit Equation Model using five variables: managed funds, the time interval from the year of launch, the owners of mutual funds, whether the fund is new or not, and the number of newcomers. Table 1 below shows the results. Table 1 Column (1) informs about the variables used. Column (2) informs the coefficients of each variable used in the Logit equation for the initial model that uses all variables. Column (3) informs about the coefficients of the variables used in the predictive model for Whole sharia mutual funds. Column (4) informs about the coefficients of the variables used in the prediction model for Equity sharia mutual funds. Column (5) informs about the coefficients of the variables used in the predictive model for Fixed income of sharia mutual funds. Column (6) informs about the coefficients of the variables used in the predictive model for Mixed sharia mutual funds. Figure 2 show the level of accuracy of each model. The level of accuracy is divided into three categories; the level of accuracy to predict persistence $(\mathrm{Dep}=1)$, the level of accuracy to predict nonpersistence $($ Dep $=0)$, and overall accuracy (TOTAL). 
Table 1: Variable Coefficients of the Predicting Persistence Models

\begin{tabular}{lccccc}
\hline \hline Variables & $\begin{array}{c}\text { Preliminary } \\
\text { Model }\end{array}$ & $\begin{array}{c}\text { Model for } \\
\text { Whole Sharia } \\
\text { Mutual Funds }\end{array}$ & $\begin{array}{c}\text { Model for } \\
\text { Equity Sharia } \\
\text { Mutual Funds }\end{array}$ & $\begin{array}{c}\text { Model for } \\
\text { Fixed-Income } \\
\text { Sharia Mutual } \\
\text { Funds }\end{array}$ & $\begin{array}{c}\text { Model for } \\
\text { Mixed Sharia } \\
\text { Mutual Funds }\end{array}$ \\
\hline \multicolumn{1}{c}{$(1)$} & $(2)$ & $(3)$ & $(4)$ & $(5)$ & $(6)$ \\
C & -1.448 & 1.108 & 3.233 & -1.708 & 1.233 \\
NEW & -0.526 & -0.363 & -1.337 & 0.505 & - \\
FUND & -0.453 & - & - & - & -1.971 \\
ADNEW & -0.202 & -0.256 & -0.568 & -0.982 & 0.184 \\
LAUNCH & -0.034 & -0.027 & -0.316 & 0.601 & -0.180 \\
OWN & -0.199 & - & - & - & - \\
\hline \hline
\end{tabular}

Figure 2: The Level of Accuracy of The Model

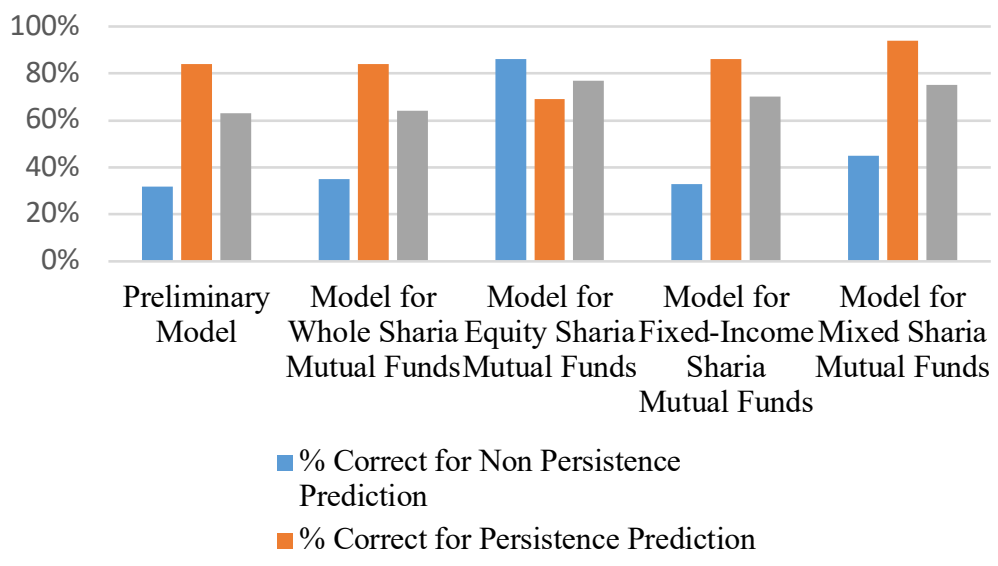

The table above shows that the coefficient of the NEW variable shows a negative sign for the Whole and Equity models but indicates a positive sign for the Fixed-Income model. For Mixed models, the NEW variable is not the best model determinant. NEW variables with negative coefficients indicate that mutual funds in the top 5 in just 1-2 years after launch, are relatively difficult to have persistence. Thus, sharia mutual funds that quickly enter the top 5 , in general, tend to be non-persistent. Overall, the findings in sharia mutual funds also apply to equity funds. Meanwhile, in fixed-income mutual funds, mutual funds that quickly enter the top 5generally have persistent performance. 
The FUND variable generally does not determine the persistence of sharia mutual funds except for mixed mutual funds. In mixed mutual funds, the greater the funds managed, the lower the likelihood that the performance is persistent. The ADNEW variable generally has a negative coefficient except for mixed mutual funds. Thus, the more the new entrants to the market, the more difficult it is to make mutual fund performance persistent. The LAUNCH variable generally also has a negative coefficient. In contrast to the ADNEW variable, where the positive coefficient is mixed mutual funds, the LAUNCH variable with a positive coefficient is fixed-income mutual funds. The ADNEW and LAUNCH variables have similarities, in terms of determinants of persistency, because they are determinants for all types of sharia mutual funds. The negative coefficient of the LAUNCH variable indicates that the longer the age of a mutual fund, the harder it is to persistently perform. The last variable is OWN. This variable turns out not to be a determinant of persistence for all types of mutual funds. Thus, the fact whether a mutual fund is owned by foreign or local investor does not determine the persistence probability of the mutual fund performance.

\subsection{Discussion}

The findings of previous studies indicating that sharia mutual funds in a given period have persistent performance while those in other periods are not persistent (see Arifin (2018) and Zheng (1999)), requires us to find out the determinants of the persistence. This research found that one of these factors is the fact whether the mutual fund is still relatively new when it reaches the top 5 . If the mutual fund is still new when it reaches the top 5, its probability to have a persistent performance is small. There is a possibility that its achievement is much influenced by external factors if the mutual fund reaches the top 5 quickly. However, if mutual funds have been launched for a long time (more than two years) when they reach the top 5, the achievement factor is most likely due to management's ability to manage funds. Nonetheless, investors are required to stay vigilant because, in mixed mutual funds, the ability for mutual funds to reach the top 5, be it quick or slow, will not become the determinant of persistence. In addition, in fixed-income mutual funds, what we found was the opposite. Fixed-income mutual funds that quickly reach the top 5 tend to have persistent performance but when they have been in the top 5 for a long time, they tend to be less persistent. The nature of fixed-income mutual funds that have stable returns may explain this occurrence. Once a mutual fund has a portfolio of debt securities with high-interest income, the mutual fund will have an advantage for several years. The advantage of the portfolio will be weakened against changes in macroeconomic factors such as changes in interest rates. Nevertheless, because interest rates will only change gradually, the impact on the top 5 ranking also lasts long because it awaits the impact of the accumulated interest rate changes.

The second factor that determines persistence is the number of newcomers. In general, the more newcomers, the harder it will be for them to have persistent performance. This finding makes sense because the more newcomers the higher the level of competition. The existence of newcomers in a certain level will shift the ranking of mutual fund performance so that there is a possibility that one or more mutual funds will come out of the top 5. Thus, the mutual funds become non-persistent. However, investors need to be vigilant because, for mixed mutual funds, the number of new entrants will even increase the probability of being persistent. It is rather difficult to explain the reason behind this finding. Mixed mutual funds are a combination of equity funds and fixedincome mutual funds. If the influence of new entrants to the persistence of equity and fixed income mutual funds is negative, it should also negatively affect mixed mutual funds. 
The third factor that determines persistence is the time interval since the mutual funds were launched. In general, the longer the time interval of a mutual fund launching, the less likely it is to be persistent. Previous research did find that persistence only lasted for a few periods. In this case, it makes sense because the longer the launch of a mutual fund, the smaller the probability of its persistence. However, this does not apply to fixed-income mutual funds. The possible argument to explain this finding is the same as the argumentation in the previous (the first factor) finding. If the portfolio of bonds has produced high returns in the first time, this advantage will last long enough.

The fourth factor that determines persistence is the amount of managed funds, but this factor only applies to mixed mutual funds. The greater the managed fund, the smaller the probability of persistence. This finding actually contradicts the basic function of mutual funds, namely to provide investment diversification facilities, as stated by Bodie, Kane, Marcus (2009). Mutual funds with large funds can diversify well, which will be difficult for individuals with limited funds. The existence of these findings, coupled with the findings of the influence of newcomers on mixed mutual funds, makes us think that there are other factors that we have not been able to find that affect the performance and persistence of the mixed mutual funds.

In this study, we also investigated mutual fund owners that we classified into domestic ownership and foreign ownership. However, this study did not find any mutual fund ownership as a determinant of mutual fund persistence. Thus, the assumption that foreign mutual funds are better is not proven in the Indonesian capital market.

In general, the persistence accuracy of the developed predictive model is quite good; that is $77 \%$ for equity mutual funds, $75 \%$ for mixed mutual funds, and $70 \%$ for fixed-income mutual funds. Nonetheless, the mutual fund predictive model for all mutual funds indicates a poor prediction accuracy rate with only $64 \%$. Each type of mutual fund does require a different model because the determinants of its persistence are also different. Therefore, the investors should only use a specific persistence of predictive model for each type of mutual fund. The accuracy level of the model in this study is classified as 'good enough' because a good prediction model should produce an accuracy level of above $90 \%$. The bankruptcy prediction model developed by Altman (1968), for example, has a $95 \%$ accuracy rate. The low accuracy level of the model in this study is due to the lack of information about the published mutual funds.

\section{CONCLUSION}

Sharia mutual funds in Indonesia in the period of 2010 to 2012 had a high degree of persistence. However, in the period of 2014 to 2016, the persistence rate saw a decrease. This study has identified the factors that affect the persistence of the mutual funds' performance and based on these factors created a persistence predictor model.

There are three factors that generally affect the level of persistence, namely; the fact whether the mutual fund is still newly launched when in the top 5, the number of newcomers, and the time interval after the launch of the mutual fund. If a mutual fund is still newly launched when it reaches the top 5, it is unlikely that it will have a persistent performance. The more newcomers, the less likely it is for a mutual fund to reach a persistent performance. The longer the time from the moment of launch, the less likely the performance will be persistent. In addition to these three 
factors, another factor, namely a large amount of managed funds also affects the persistence level, but the effect is only on mixed mutual funds.

The persistence accuracy of the predictive model, in general, is quite good, with $77 \%$ for equity mutual funds, $75 \%$ for mixed mutual funds, and $70 \%$ for fixed-income mutual funds. However, the prediction model for mutual funds as a whole has a poor level of accuracy, with only $64 \%$. Therefore, investors should only use a special persistence of predictive model for each type of mutual fund as a reference for investing in sharia mutual funds.

\section{ACKNOWLEDGEMENT}

The authors would like to thank the Directorate of Research and Community Service, and Directorate General of Research and Development Reinforcement of Ministry of Research, Technology and Higher Education of Indonesia for funding this research. The authors are also grateful for colleagues in the Department of Management of Universitas Islam Indonesia for their considerable inputs throughout the preparation of this research.

\section{REFERENCES}

Abderrezak, F. (2008). The Performance of Islamic Equity Funds: A Comparison to Conventional, Islamic and Ethical Benchmarks. Thesis, University of Maastricht, Netherlands.

Altman, E. I. (1968). Financial ratios, discriminant analysis and the prediction of corporate bankruptcy. The Journal of Finance, 23(4), 589-609.

Arifin, Z., \& Mulyati, S. (2017). Relative Short-Term Persistence and Absolute Short-Term Persistence of Islamic Mutual Funds in Indonesia. Advances in Economics, Business and Management Research (AEBMR), 35, 94-100.

Arifin, Z. (2018). Testing for Persistence in Sharia Mutual Fund Performance in Indonesia, Review of Integrative Business and Economics Research, 7(1), 104-115.

Bodie, Z., Kane, A., \& Marcus, A. J. (2009). Investment. New York: McGraw-Hill Irwin.

Carhart, M. M. (1997). On Persistence in Mutual Fund Performance, The Journal of Finance, 52(1), 57-82.

Dabbeeru, R. N. (2006). Performance Analysis of Mutual Funds in Saudi Arabia. SSRN eLibrary. doi: http://dx.doi.org/10.2139/ssrn.921523

Dwianggoro, A., Anantadjaya, S. P. \& Sibarani, M. (2012). Equity Mutual Funds in Indonesia: Persistence Analysis Period April 2006 - March 2011. Finance \& Accounting Journal, 1(2), 69-83.

Elfakhani, S., Hassan, M. K., \& Sidani, Y. (2005). Comparative Performance of Islamic Versus Secular Mutual Funds, Proceeding of Economic Research Forum Conference 2005, Cairo: Egypt

Elvani, V., \& Linawati, N. (2013). Consistency Test of Stock Fund Performance in Indonesia Stock Exchange Period 2008-2012, FINESTA, 1(2), 130-135.

Grinblatt M., \& Titman, S. (1992). The Persistence of Mutual Fund Performance, The Journal of Finance, 67(5), 1977-1984. 
Gruber, J. M. (1996), Another Puzzle: The Growth in Actively Managed Mutual Fund. The Journal of Finance, 51(3), 783-810.

Hayat, R., \& Kraeussl, R. (2012). Risk and Return Characteristics of Islamic Equity Funds. Emerging Market Review, 12(2), 189-203.

Jones, S., Laan, S. van der., Frost, G., \& Loftus, J. (2008). The Investment Performance of Socially Responsible Investment Funds in Australia. Journal of Business Ethics, 80, 181-203.

Khamlichi, A., Arouri, M., \& Teulon, F. (2014). Persistence of Performance Using The FourFactor Pricing Model: Evidence from Dow Jones Islamic Index. The Journal of Applied Business Research, 30(3), 917- 926.

Mansor, F., \& Bhatti, M. I. (2011, March 14-16). The Islamic Mutual Fund Performance: New Evidence on Market Timing and Stock Selectivity, Proceeding 2011 International Conference on Economics and Finance Research (ICEFR), Langkawi, Malaysia.

Norman, L Trevor, (2004). Islamic Investment Funds, in Sahail Jaffer (Editor), Islamic Asset Management, Euromoney Book- Kuwait Finance House- The National Commercial Bank, London, United Kingdom

Rahman, A. (2013). Comparative Analysis of Shari'a Mutual Fund Performance and Conventional Mutual Funds in Crisis Period and Subsequent Crisis Subprime Mortgage, Master Thesis, Universitas Gadjah Mada, Indonesia.

Romadon, G. (2012). Comparative Analysis of Sharia and Conventional Mutual Performance Using RMAR and RDIV, Master Thesis, Universitas Gadjah Mada, Indonesia.

Rubio, J. F., Hassan, M. K., \& Merdad, H. J. (2012). Non-Parametric Performance Measurement of International and Islamic Mutual Funds. Accounting Research Journal, 25(3), 208-226.

Susanto, H. A. (2012). Comparative Analysis of Conventional Mutual Fund Performance and Syariah Mutual Funds Using Sharpe Model, Treynor, Reward to Market Risk, and Reward to Diversification, Master Thesis, Universitas Gadjah Mada, Indonesia.

Zheng, L. (1999). Is Money Smart? A Study of Mutual Fund Investor's Fund Selection Ability. The Journal of Finance, 54(3), 901-933. 
Appendix: Samples of the Study

\begin{tabular}{|c|c|c|c|c|c|}
\hline No & $\begin{array}{l}\text { Sharia Equity Mutual } \\
\text { Funds }\end{array}$ & No & $\begin{array}{c}\text { Sharia Fixed Income } \\
\text { Mutual Funds }\end{array}$ & No & Sharia Mixed Mutual Funds \\
\hline 1 & $\begin{array}{l}\text { Avrist Equity- amar } \\
\text { Syariah }\end{array}$ & 1 & $\begin{array}{l}\text { Mandiri Investa Dana } \\
\text { Syariah }\end{array}$ & 1 & $\begin{array}{l}\text { Asanusa Amanah Syariah } \\
\text { Fund }\end{array}$ \\
\hline 2 & $\begin{array}{l}\text { BNP Paribas Pesona } \\
\text { syariah }\end{array}$ & 2 & MNC Dana Syariah & 2 & $\begin{array}{l}\text { Asia Raya Syariah Taktis } \\
\text { Berimbang }\end{array}$ \\
\hline 3 & Bahana icon syariah & 3 & PNM Amanah Syariah & 3 & $\begin{array}{l}\text { Avrist Balanced - Amar } \\
\text { Syariah }\end{array}$ \\
\hline 4 & $\begin{array}{l}\text { Batavia Dana Saham } \\
\text { Syariah }\end{array}$ & 4 & $\begin{array}{l}\text { Danareksa Melati } \\
\text { Pendapatan }\end{array}$ & 4 & $\begin{array}{l}\text { CIMB Principal Islamic } \\
\text { Growth Syariah }\end{array}$ \\
\hline 5 & Cipta Syariah Equity & 5 & $\begin{array}{l}\text { Majoris Sukuk Negara } \\
2016\end{array}$ & 5 & $\begin{array}{l}\text { CIMB Principal Balanced } \\
\text { Strategic Plus }\end{array}$ \\
\hline 6 & $\begin{array}{l}\text { Danareksa Syariah } \\
\text { saham }\end{array}$ & 6 & Maybank Sukuk syariah & 6 & $\begin{array}{l}\text { Cipta Nusantara syariah } \\
\text { Berimbang }\end{array}$ \\
\hline 7 & HPAM Syariah Ekuitas & 7 & $\begin{array}{l}\text { PNM Sukuk Negara } \\
\text { Syariah }\end{array}$ & 7 & Cipta Syariah Balance \\
\hline 8 & KAM Kapital Syariah & 8 & Bahana Sukuk Syariah & 8 & Danareksa Syariah Berimbang \\
\hline 9 & $\begin{array}{l}\text { Lautandhana Saham } \\
\text { syariah }\end{array}$ & 9 & $\begin{array}{l}\text { Primier Fixed Income } \\
\text { syariah }\end{array}$ & 9 & Insight Syariah Berimbang \\
\hline 10 & $\begin{array}{l}\text { MNC Dana Syariah } \\
\text { Ekuitas }\end{array}$ & 10 & $\begin{array}{l}\text { BNI AM Dana Dompet } \\
\text { Dhufa }\end{array}$ & 10 & $\begin{array}{l}\text { MNC Dana Syariah } \\
\text { Kombinasi }\end{array}$ \\
\hline 11 & $\begin{array}{l}\text { Mandiri Investa } \\
\text { atraktif Syariah }\end{array}$ & 11 & I Hajj Syariah Fund & 11 & $\begin{array}{l}\text { Mandiri Investa Syariah } \\
\text { Berimba }\end{array}$ \\
\hline 12 & $\begin{array}{l}\text { Mandiri Investa } \\
\text { Ekuitas Syariah }\end{array}$ & 12 & $\begin{array}{l}\text { SAM SUKUK Syariah } \\
\text { Sejahtera }\end{array}$ & 12 & Mega Asset Madania Syariah \\
\hline 13 & $\begin{array}{l}\text { Manulife syariah } \\
\text { Sektoral Aman }\end{array}$ & 13 & Medali Syariah & 13 & PNM Syariah \\
\hline 14 & $\begin{array}{l}\text { Maybank Syariah } \\
\text { equity Fund }\end{array}$ & 14 & $\begin{array}{l}\text { Archipelago Sukuk } \\
\text { Syariah } 1\end{array}$ & 14 & Pacific Balance Syariah \\
\hline 15 & $\begin{array}{l}\text { OSO Syariah Equity } \\
\text { Fund }\end{array}$ & 15 & $\begin{array}{l}\text { Avrist Sukuk Income } \\
\text { Fund }\end{array}$ & 15 & $\begin{array}{l}\text { Panin Dana Syariah } \\
\text { Berimbang }\end{array}$ \\
\hline 16 & PNM Ekuitas Syariah & 16 & $\begin{array}{l}\text { BNI AM Dana } \\
\text { Pendapatan Tetap }\end{array}$ & 16 & Pratama Syariah Imbang \\
\hline 17 & Pacific Saham Syariah & & & 17 & Cipta Syariah Balance \\
\hline 18 & $\begin{array}{l}\text { Panin Dana Syariah } \\
\text { Saham }\end{array}$ & & & 18 & SAM Syariah Berimbang \\
\hline 19 & Pratama Syariah & & & 19 & $\begin{array}{l}\text { Schroder Syariah Balanced } \\
\text { Fund }\end{array}$ \\
\hline 20 & $\begin{array}{l}\text { Reliance Saham } \\
\text { Syariah }\end{array}$ & & & 20 & Simas Syariah Balance Fund \\
\hline 21 & $\begin{array}{l}\text { SAM Sharia Equity } \\
\text { Fund }\end{array}$ & & & 21 & Trim Syriah Berimbang \\
\hline 22 & $\begin{array}{l}\text { Simas Syariah } \\
\text { Unggulan }\end{array}$ & & & & \\
\hline 23 & $\begin{array}{l}\text { Sucorinvest Sharia } \\
\text { Equity Fund }\end{array}$ & & & & \\
\hline 24 & $\begin{array}{l}\text { Sucorinvest Sharia } \\
\text { Saham Dinamis }\end{array}$ & & & & \\
\hline 25 & Trim Syariah Saham & & & & \\
\hline
\end{tabular}

